\title{
Development and Validation of Stability Indicating RP-HPLC Method for Estimation of Larotrectinib in its Formulations
}

\author{
MAHREEN FATIMA ${ }^{1}$, ANUPAMA KONERU ${ }^{2}$, M.MUSHRAFF ALI KHAN ${ }^{3}$, \\ MURALI BALARAM VARANASI ${ }^{1}$ and IMAM PASHA SYED ${ }^{1 *}$
}

1Department of Pharmaceutical Quality Assurance, Sultan-ul-Uloom College of Pharmacy, Mount
Pleasant, \#8-2-249, Road No.3, Banjara hills, Hyderabad-500034, Telangana, India.
'Department of Pharmacology, Sultan-ul-Uloom College of Pharmacy, Mount Pleasant,
\#8-2-249, Road No.3, Banjara hills, Hyderabad-500034, Telangana, India.
${ }^{3}$ Department of Pharmaceutics, Sultan-ul-Uloom College of Pharmacy, Mount Pleasant,
\#8-2-249, Road No.3, Banjara hills, Hyderabad-500034, Telangana, India.

*Corresponding author E-mail: impazam@gmail.com, imampharmaceuticalsciences@gmail.com

http://dx.doi.org/10.13005/ojc/360216

(Received: November 14, 2019; Accepted: April 11, 2020)

\begin{abstract}
A stability indicating HPLC method for the quantification of Larotrectinib in capsule form was developed and validated as per the $\mathrm{ICH}$ guidelines. Separation and quantification of Larotrectinib was carried out on column Sunsil $\mathrm{C}_{18}$ using mobile phase as $\mathrm{KH}_{2} \mathrm{PO}_{4}$ and methanol in 1:1 ratio. Larotrectinib was eluted at 3.432 minutes. Linearity was observed in between $50-150 \mu \mathrm{g} / \mathrm{ml}$. LOD and LOQ were found to be $0.065 \mu \mathrm{g} / \mathrm{ml}$ and $0.217 \mu \mathrm{g} / \mathrm{ml}$ respectively. \% RSD for the precision of the method was found to be 0.115 . Accuracy was well within the regulated limit that is $100.13 \%$ and the recovery was found to be to $100.47 \%$. Forced degradation analysis was carried out on Larotrectinib which established stability indicating power of the developed method.
\end{abstract}

Keywords: HPLC, Larotrectinib, Method development, ICH Guidelines.

\section{INTRODUCTION}

A medication, Vitrakvi (Larotrectinib), IUPAC term (3S)-N-\{5-[(2R)-2-(2,5-difluorophenyl)-1pyrrolidinyl]pyrazolo[1,5-a]pyrimidin-3-yl\}-3-hydroxy1-pyrrolidinecarboxamidesulphate was authorized by US Food \& Drug Administration (FDA) to manage tumors with particular genetic modification regardless of cancer type. Vitrakvi (Larotrectinib) is authorized for managing adults and children having solid tumors which give positive test for NTK genes ${ }^{1}$. Tumors with that kind of genetic modification are not prevalent but it can be seen in salivary gland cancer, pulmonary cancer and sarcoma in tissue. Tumors which have distributed or not surgically removed and have grew up during earlier medicines must be treated with Larotrectinib. Present work is aimed to develop a new, efficient and reproducible HPLC method for

This is an Open Access article licensed under a Creative Commons license: Attribution 4.0 International (CC- BY). Published by Oriental Scientific Publishing Company @ 2018

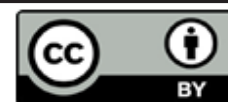


the analysis of Larotrectinib. The developed method is validated according to $\mathrm{ICH}$ guidelines for various parameters specified in guidelines ${ }^{2,3,4}$. Separation and quantification of Larotrectinib was carried on column Sunsil $\mathrm{C}_{18}$ using mobile phase as $\mathrm{KH}_{2} \mathrm{PO}_{4}$ and methanol in 1:1 ratio. Larotrectinib was eluted at 3.432 minutes. The method was validated for parameters such as specificity, linearity, precision, accuracy, system suitability, limit of detection, limit of quantification and robustness.

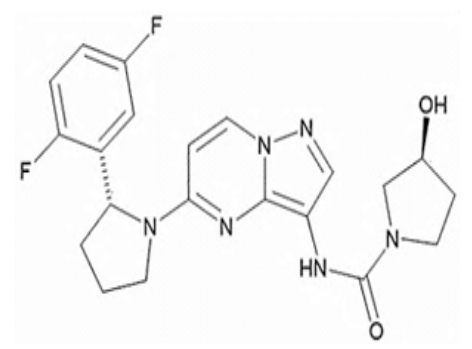

Fig. 1. Larotrectinib structure

\section{MATERIAL AND METHODS}

Table 1: Instruments used

\begin{tabular}{ccc}
\hline Instrument & Model & Description \\
\hline HPLC system & 2695 model & Water alliance \\
Column & Sunsil $\mathrm{C}_{18}$ & $250 \mathrm{~mm} \times 4.6 \mathrm{~mm}, 5 \mu \mathrm{m}$ \\
Software & Empower & Water alliance \\
Photodiode array & 2998 Model & Water alliance \\
\hline
\end{tabular}

Table 2: Drug, chemicals and solvents used

\begin{tabular}{ll}
\hline Material & Source \\
\hline Larotrectinib & Octapharma pvt.Itd, India \\
Dipotassium hydrogen phosphate & Sd Fine-Chem Ltd, India \\
Hydrochloric acid & Sd Fine-Chem Ltd, India \\
Sodium hydroxide & Sd Fine Chem Ltd, India \\
Hydrogen peroxide & Sd Fine Chem Ltd, India \\
Phosphoric acid & Sd Fine Chem Ltd, India \\
Methanol & Merck specialities Ltd, \\
& India \\
\hline
\end{tabular}

Table 3: HPLC method conditions

\begin{tabular}{lc}
\hline Column with temperature & Ambient \\
\hline $\mathrm{pH}$ units & 4.3 units \\
Injection vol sample & $10 \mu \mathrm{l}$ \\
Column rate of flow & $1 \mathrm{ml} / \mathrm{min}$ \\
Run time & $5 \mathrm{minutes}$ \\
wave length of detection & $228 \mathrm{~nm}$ \\
\hline
\end{tabular}

\section{Preparation of mobile phase}

$\mathrm{KH}_{2} \mathrm{PO}_{4}$ with strength $0.1 \mathrm{M}$ and methanol mixed in 50:50 v/v ratios and the $\mathrm{pH}$ was fixed to
4.3 with the aid of phosphoric acid. As both mobile phase and diluent, this solvent mix was used.

\section{Preparation of stock solution}

$100 \mathrm{mg}$ of standard Larotrectinib was dissolved in $100 \mathrm{~mL}$ volume of mobile phase. Stock Larotrectinib solution-1000 $\mu \mathrm{g} / \mathrm{ml}$ concentration.

\section{Assay methodology}

Larotrectinib capsules (label claim - 100 $\mathrm{mg} /$ capsule) were emptied. Capsule powder weight equivalent to $100 \mathrm{mg}$ Larotrectinib was taken to standard flask (100 mL). $25 \mathrm{~mL}$ mobile phase was added and dissolved and make up the volume to $100 \mathrm{~mL}$. Concentration of Larotrectinib in solution (stock capsule solution) was $1000 \mu \mathrm{g} / \mathrm{ml} .1 \mathrm{~mL}$ stock capsule solution is mixed with $9 \mathrm{~mL}$ of diluent. Then concentration of Larotrectinib in this capsule solution was $100 \mu \mathrm{g} / \mathrm{mL}$. This capsule solution was analyzed employing proposed HPLC conditions. The Larotrectinib amount in capsule was calculated with acquired peak areas.

\section{ASSAY\%:

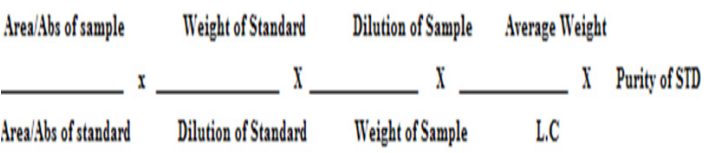

Table 4: Optimized chromatographic conditions

\begin{tabular}{lc}
\hline Mobile Phase & $\begin{array}{c}\mathrm{Na}_{2} \mathrm{HPO}_{4}(50 \mathrm{~mL} \text { and } \\
\text { methanol }(50 \mathrm{~mL})\end{array}$ \\
\hline $\mathrm{pH}$ of mobile phase & 4.3 \\
Chromatographic column & $\begin{array}{c}\text { Phenomenex, } \mathrm{C}_{18}, \text { length }-250 \mathrm{~mm}, \\
\text { Identification }-4.6 \mathrm{~mm}, \text { particle }-5 \mu \mathrm{m}\end{array}$ \\
Flow Rate & $1.0 \mathrm{ml} / \mathrm{min}$ \\
Injection Volume & $10 \mu \mathrm{l}$ \\
Temperature of column & $25^{\circ} \mathrm{C}$ \\
Detection wavelength & $228 \mathrm{~nm}$ \\
Time of run & $5 \mathrm{minutes}$ \\
\hline
\end{tabular}

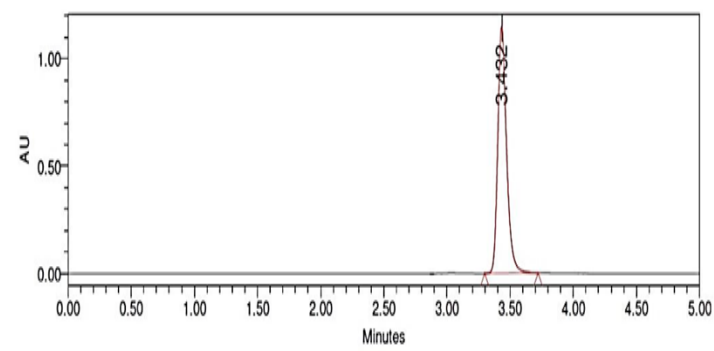

Fig. 2. Chromatogram with optimized conditions 


\section{Assay of formulation}

Standard and sample solutions were injected separately into the system and chromatograms were recorded. The drug present in sample was calculated using mentioned formula.

Table 5: Assay of formulation

\begin{tabular}{cc}
\hline S.No & \% Assay \\
\hline 1 & 99 \\
2 & 99 \\
3 & 99 \\
4 & 99 \\
5 & 99 \\
6 & 100 \\
Average assay: & 99 \\
Standard deviation & 0.11 \\
\%RSD & 0.12 \\
\hline
\end{tabular}

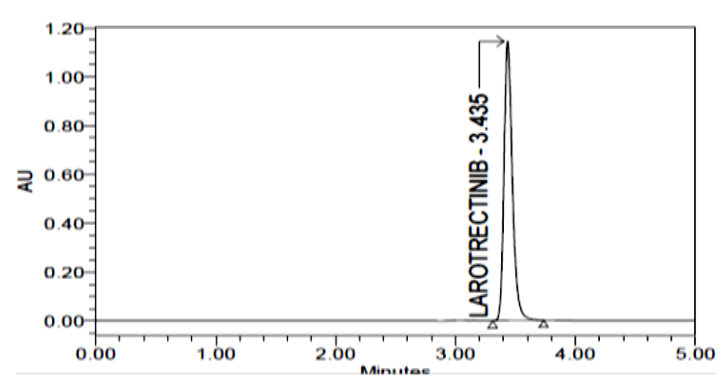

Fig. 3. Sample chromatogram

\section{Method validation ${ }^{5,6,7}$ \\ Selectivity}

Interference of blank diluent, placebo and excipient in capsule solution was assessed. Analysis was done on blank diluent, placebo and excipient in capsule solution and compared with Larotrectinib standard $(100 \mu \mathrm{g} / \mathrm{mL})$. Interference peaks were not noticed at the retention time of Larotrectinib in chromatograms of blank diluent, placebo and capsule solution. This clearly showed ability of method to selectively analyze Larotrectinib.

\section{System suitability}

To test system effectiveness $10 \mu \mathrm{l}$ of Larotrectinib standard $(100 \mu \mathrm{g} / \mathrm{mL})$ injected five times. Result of system suitability (Plate count, RSD of peak area, retention time and tailing factor) were computed. The results were well within the limits of $\mathrm{ICH}$ prescribed.

\section{Prescribed limits}

- $\quad$ More than 2000-Plate count

- $\quad$ Less than or equal to $2 \%$ - Peak area RSD

- Retention time- reliably less

- Less than or equal to $2 \%$ - Tailing factor
Sample- Blank Sample- Placebo

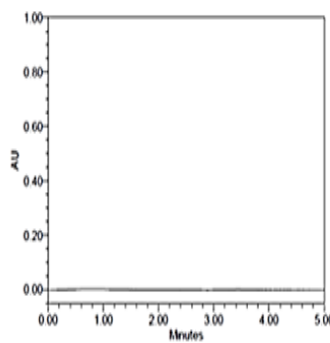

Sample - Standard
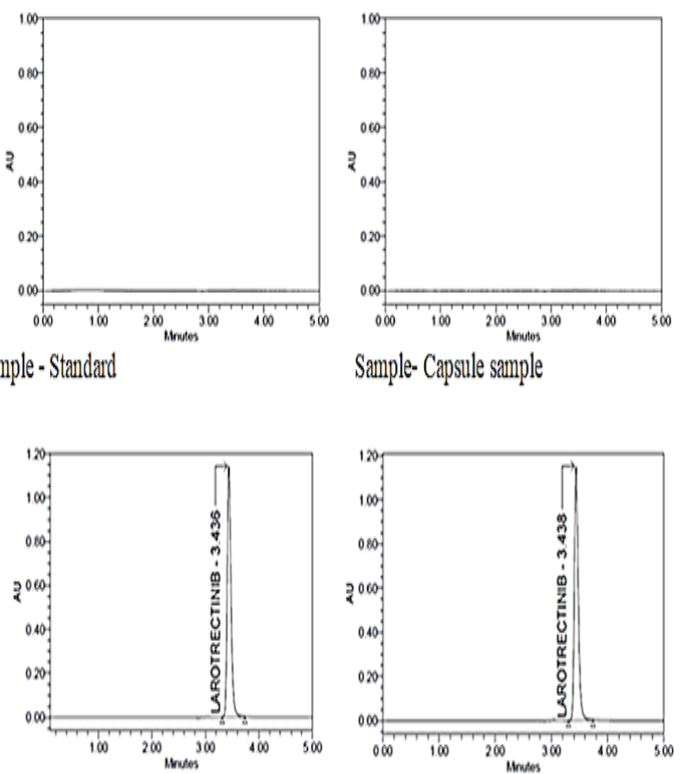

Fig.4. Selectivity evaluation chromatograms

Table 6: Results for system suitability

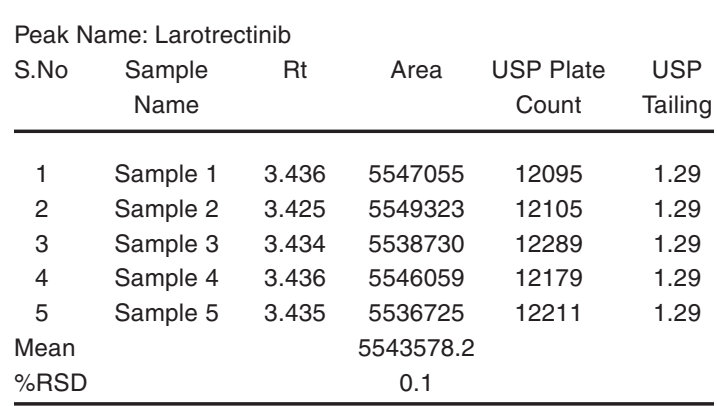

\section{Linearity}

Five calibration samples of Larotrectinib were made $(50 \mu \mathrm{g} / \mathrm{mL}, 75 \mu \mathrm{g} / \mathrm{mL}, 100 \mu \mathrm{g} / \mathrm{mL}$, $125 \mu \mathrm{g} / \mathrm{mL}$ and $150 \mu \mathrm{g} / \mathrm{mL}$ ) and injected into chromatographic system. Plot the graph of measured Peak area Vs. concentration and calculated the regression coefficient. Good linear relationship is observed with correlation coefficient of 0.9998 .

Table 7: Results of linearity

\begin{tabular}{ccc}
\hline $\begin{array}{l}\text { \%Concentration } \\
\text { with respect to } \\
\text { target conc. }\end{array}$ & Larotrectinib area & $\begin{array}{c}\text { Larotrectinib } \\
\text { conc. }(\mu \mathrm{g} / \mathrm{ml})\end{array}$ \\
\hline 50 & & \\
75 & 2767034 & 50 \\
100 & 4153769 & 75 \\
125 & 5539444 & 100 \\
150 & 6921686 & 125 \\
\hline
\end{tabular}




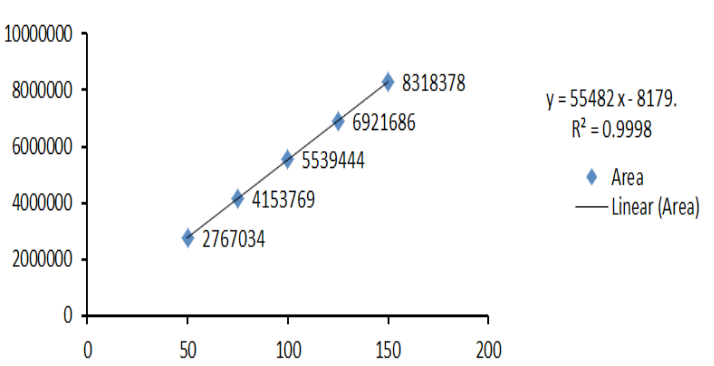

Fig. 5. Larotrectinib linearity graph

\section{LOD and LOQ}

The concentration of Larotrectinib with signal to noise ratio $3: 1$ is taken as LOD and 10:1 as LOQ.

Table 8: Signal to noise details in LOD and LOQ

\begin{tabular}{ccccc}
\hline S.No & Sample name & Rt & Area & S/N ratio \\
\hline 1 & LOD & 3.531 & 31853 & 3.96 \\
2 & LOQ & 3.537 & 29391 & 10.28 \\
\hline
\end{tabular}

Sample Name- LOD

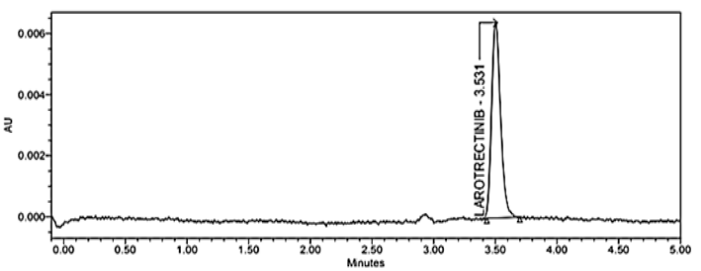

Sample Name-LOQ

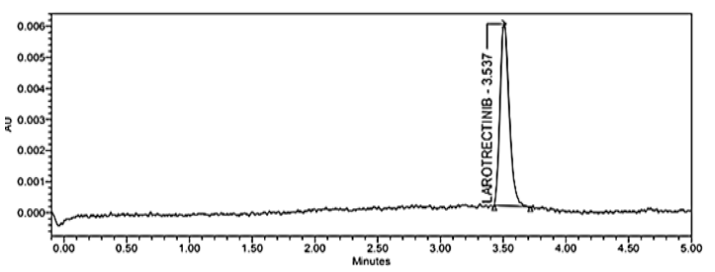

Fig. 6. Sensitivity evaluation chromatograms

\section{Precision}

Standard Larotrectinib solution is injected ( $n=6$ times) in the system. Measured mean area and RSD for 6 injections. The RSD for area of 6 injections is lower than $2 \%$, which shows good precision.

Table 9: Results of precision

\begin{tabular}{cc}
\hline \multicolumn{2}{c}{ Larotrectinib-100 mg } \\
\hline S.No & Area \\
& \\
1 & 5529736 \\
2 & 5525264 \\
3 & 5523125 \\
4 & 5523255 \\
5 & 5530329 \\
6 & 5539924 \\
Average area & 5528803 \\
STD & 0.114 \\
\%RSD & 0.115 \\
\hline
\end{tabular}

Injection-1

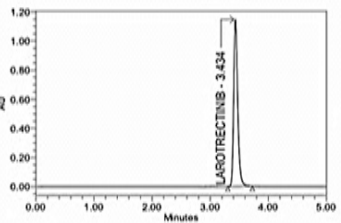

Injection-2

Injection-3

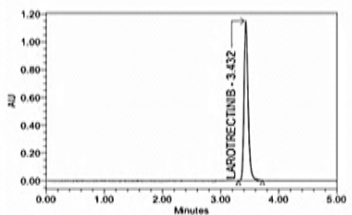

Injection-5
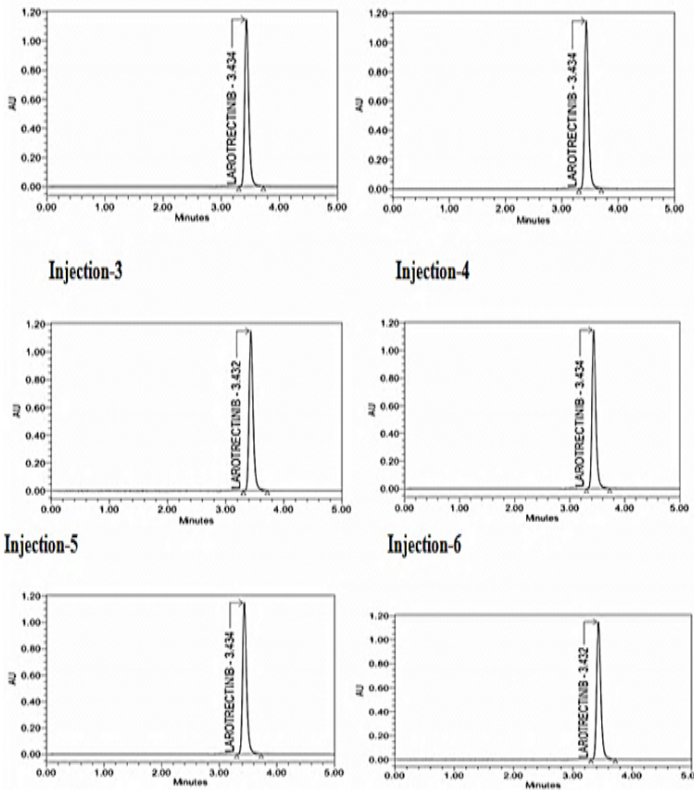

Injection-4

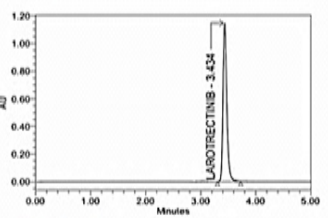

Injection-6

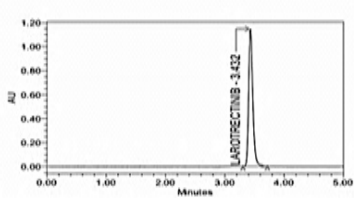

Fig. 7.Precision evaluation chromatograms

\section{Accuracy}

Accuracy was determined through analysis $(n=3)$ for different three concentrations $(49.5 \mu \mathrm{g} /$ $\mathrm{mL}$ - 50\% level; $99 \mu \mathrm{g} / \mathrm{mL}$ - 100\% level; $148.5 \mu \mathrm{g} /$ $\mathrm{mL}-150 \%$ level) of Larotrectinib spiked to already analyzed capsule solution. Mean recovery at different three concentrations were computed. The values are nearby $100 \%$, which shows good accuracy.
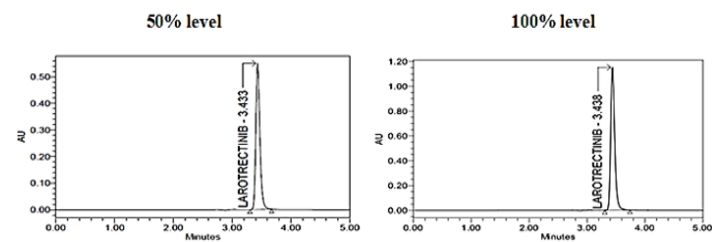

$150 \%$ level

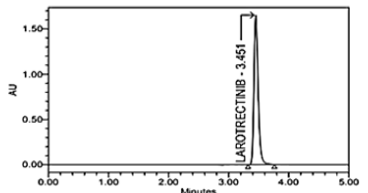

Fig. 8. Accuracy evaluation chromatograms

\section{Robustness}

Robustness was checked by determining parameters for system suitability by making small but deliberate variations in assay conditions as given.

- $\quad$ Flow 1: $0.9 \mathrm{~mL} / \mathrm{min}$ 


$\begin{array}{ll}- & \text { Flow } 2: 1.1 \mathrm{ml} / \mathrm{min} \\ \text { - } & \text { Temperature } 1: 23^{\circ} \mathrm{C} \\ \text { - } & \text { Temperature } 2: 27^{\circ} \mathrm{C}\end{array}$

- $\quad \mathrm{pH} 1: 4.1$ unit

- $\quad \mathrm{pH} 2: 4.5$ unit

- Methanol composition at $45 \%$ and $55 \%$

Table 10: Results of accuracy evaluation

\begin{tabular}{ccccc}
\hline Level added & Larotrectinib area & $\mu \mathrm{g} / \mathrm{ml}$ Larotrectinib added & $\mu \mathrm{g} / \mathrm{ml}$ Larotrectinib found & \%Larotrectinib recover \\
\hline $50 \%$ & 2755478 & 49.500 & 49.56 & 100.11 \\
$50 \%$ & 2756510 & 49.500 & 49.58 & 100.15 \\
$50 \%$ & 2755948 & 49.500 & 49.57 & 100.13 \\
$100 \%$ & 5525880 & 99.000 & 99.38 & 100.39 \\
$100 \%$ & 5520131 & 99.000 & 99.28 & 100.28 \\
$100 \%$ & 5527423 & 99.000 & 99.41 & 100.36 \\
$150 \%$ & 8295365 & 148.500 & 149.19 & 100.41 \\
$150 \%$ & 8292770 & 148.500 & 149.14 & 100.46 \\
$150 \%$ & 8298628 & 148.500 & 149.25 & 100.47 \\
\hline
\end{tabular}

Table 11: Results of robustness evaluation

\begin{tabular}{ccccc}
\hline & \multicolumn{3}{c}{ Peak name : Larotrectinib } \\
Sample name & Rt & Area & USP Tailing & USP plate count \\
\hline Flow-1 & 2.937 & 4687232 & 1.26 & 11621 \\
Flow-2 & 3.235 & 5215096 & 1.27 & 11925 \\
Temp-1 & 4.026 & 6541959 & 1.29 & 12290 \\
Temp-2 & 4.618 & 7286964 & 1.28 & 13298 \\
Comp-1 & 2.937 & 4687232 & 1.26 & 11621 \\
Comp-2 & 4.026 & 6541959 & 1.29 & 12290 \\
pH-1 & 3.433 & 5539736 & 1.28 & 12237 \\
pH-2 & 3.435 & 5545264 & 1.28 & \\
\hline
\end{tabular}

There were no substantial changes to the values. This proves the robustness of the method

\section{Degradation/Stability test for Larotrectinib}

Stability check/degradation study of Larotrectinib was carried out using $\mathrm{ICH}$ criterion with capsule solution of $1000 \mu \mathrm{g} / \mathrm{ml}$ concentration.

\section{Acid degradation ${ }^{8-12}$}

$1 \mathrm{~mL}$ of stock Larotrectinib solution is mixed with $1 \mathrm{~mL} 0.1 \mathrm{~N} \mathrm{HCl}$ followed by sonication for nearly $30 \mathrm{~min}$ at $25 \pm 2^{\circ} \mathrm{C}$ temperature. The mixture was made to $10 \mathrm{~mL}$ volume by diluent $(100 \mu \mathrm{g} / \mathrm{mL})$. This degraded capsule solution was analyzed employing proposed HPLC conditions. The Larotrectinib amount degraded and remained in capsule was calculated with acquired peak areas.

\section{Ikali degradation ${ }^{13,14}$}

$1 \mathrm{~mL}$ of stock Larotrectinib solution is mixed with $1 \mathrm{~mL} 0.1 \mathrm{~N} \mathrm{NaOH}$ followed by sonication for nearly $30 \mathrm{~min}$ at $25 \pm 2^{\circ} \mathrm{C}$ temperature. The mixture was made to $10 \mathrm{~mL}$ volume by diluent (theoretical Larotrectinib concentration - $100 \mu \mathrm{g} / \mathrm{mL}$ ). This degraded capsule solution was analyzed employing proposed HPLC conditions. The Larotrectinib amount degraded and remained in capsule was calculated with acquired peak areas.

\section{Peroxide degradation ${ }^{15,16}$}

$1 \mathrm{~mL}$ of stock Larotrectinib solution is mixed with $1 \mathrm{~mL}$ of $30 \%$ hydrogen peroxide followed by sonication for nearly $30 \mathrm{~min}$ at $25 \pm 2^{\circ} \mathrm{C}$ temperature. The mixture was made to $10 \mathrm{~mL}$ volume by diluent (theoretical Larotrectinib concentration - $100 \mu \mathrm{g} / \mathrm{mL}$ ).

This degraded capsule solution was analyzed employing proposed HPLC conditions. The Larotrectinib amount degraded and remained in capsule was calculated with acquired peak areas.

\section{Thermal degradation ${ }^{17-19}$}

Capsule powder weight similar to $100 \mathrm{mg}$ Larotrectinib was placed in petri plate and exposed to $100^{\circ} \mathrm{C}$ for nearly 6 hours. Cool the sample to $25 \pm 2^{\circ} \mathrm{C}$ temperature and transfer to standard flask $(100 \mathrm{~mL})$. To which $25 \mathrm{~mL}$ of mobile phase added and dissolved and make up the volume to $100 \mathrm{~mL}$. 
$1 \mathrm{~mL}$ prepared solution is mixed with $9 \mathrm{~mL}$ diluent (theoretical Larotrectinib concentration - $100 \mu \mathrm{g} /$ $\mathrm{mL}$ ). This capsule solution was analyzed employing proposed HPLC conditions. The Larotrectinib amount in capsule was calculated with acquired peak areas.

\section{Photo degradation ${ }^{20-23}$}

Capsule powder weight equivalent to $100 \mathrm{mg}$ Larotrectinib was placed in petri plate and exposed to sunlight for nearly 6 hours. Cool the sample to $25 \pm 2^{\circ} \mathrm{C}$ temperature and transfer to standard flask (100 mL). $25 \mathrm{~mL}$ mobile phase added and dissolve the drug through sonication. Mobile phase volume of $75 \mathrm{~mL}$ is added and properly mixed. $1 \mathrm{~mL}$ of prepared solution is mixed with $9 \mathrm{~mL}$ of diluent (theoretical Larotrectinib concentration - $100 \mu \mathrm{g} / \mathrm{mL}$ ). This capsule solution was analyzed employing proposed HPLC conditions. The Larotrectinib amount in capsule was calculated with acquired peak areas.

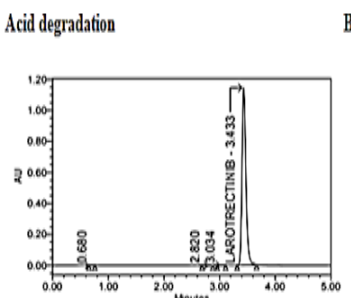

Base degradation

Peroxide degradation

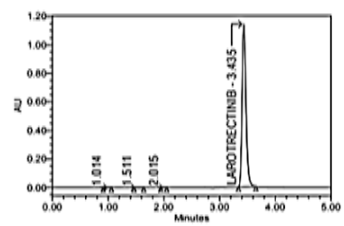

Thermal degradation

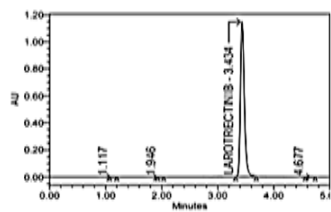

Photolytic effect

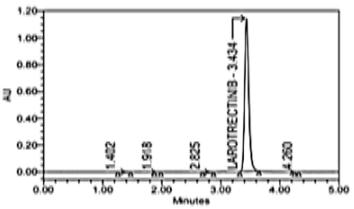

Fig. 9. Specificity/stability indicating evaluation chromatograms

Table 12: Results of Larotrectinib stability evaluation

\begin{tabular}{cccc}
\hline Condition & Larotrectinib area after degradation & \% remained after degradation & \% remained after stress applied \\
\hline Acid & 4902388 & 88.17 & 11.83 \\
Alkali & 5211566 & 93.73 & 6.27 \\
Peroxide & 5388047 & 96.9 & 3.1 \\
Thermal & 5020477 & 90.29 & 9.71 \\
Photolytic & 5296807 & 95.26 & 4.74 \\
\hline
\end{tabular}

The generation of separate peaks with distinct retention times with the peak of Larotrectinib showed its degradation. The retention time of additional peaks was completely different from retention time of Larotrectinib which proved specificity and stability indicating power.

\section{DISCUSSION}

The method development and validation of Larotrectinib was performed and the results were within the guidelines as mentioned in the standards i.e. the relative standard deviation was found to be not more than $2 \%$, method precision was found to be not more than $2.0 \%$, accuracy was found to be between $98 \%$ - 102\%, robustness was found to be within the regulated limits.

\section{CONCLUSION}

In the present investigation a simple, sensitive and accurate RP-HPLC procedure was developed for evaluation of Larotrectinib in capsule dosage form. Degradation analysis was done and concluded that Larotrectinib is more stable in peroxide and less stable in acid form. From the above studies it was concluded that the proposed RP-HPLC method can be successfully used for the estimation of Larotrectinib in capsule form. This method can be used for the routine analysis in research institutions, QC departments of the pharmaceutical industries.

\section{ACKNOWLEDGMENT}

Authors are thankful to Management \& 
Principal of Sultan-ul-Uloom College of pharmacy,

for providing research facilities for this work.

\section{Conflicts of Interests}

The authors declare that they have no conflict of interest.

\section{REFERENCES}

1. Drilon, A.; Laetsch, T.W.; Kummar, S., Engl. J. Med., 2018, 378,731-39.

2. ICH Q2A; Guidelines on validation of analytical procedure; Definitions and terminology, Federal Register., 1995, 60, 11260.

3. $\mathrm{ICH}$ Q2B; Guidelines on validation of analytical procedure; Methodology, Federal Register., 1996, 60, 27464.

4. $\quad \mathrm{ICH}$ harmonized tripartite guideline, stability testing of new drug substances and products, Q1A $\left(R^{2}\right)$., 2003, 1-15.

5. Geetha, M.; Venkat, R.; ShakilL, S.; Sripal, R. P., Orient. J. Chem., 2013, 29, 579-87.

6. Lloyd,B., Physics and Engineering Sciences., 2008, 366(1879), 3301-3318.

7. Arévalo, J.C.; Wu, S.H., Cell and Molecular Life Sciences., 2006, 63(13), 1523-1537.

8. Kawamura, K.; Kawamura, N.; Fukuda, J., J.Dev. Biology., 2007, 311(1), 147-158.

9. Heidurnezhad, Z.; Heydari, F.; Bahranian, E., Orient. J. Chem., 2013, 29(1), 69-74.

10. Kawamura, K.; Kawamura, N.; Kumazawa, Y., J. of Endocrinology., 2011, 152(3), 1090-1100.

11. Kawamura, K.; Kawamura, N.; Sato, W., Journal of Endocrinology., 2009, 150(8), 3774-3782.
12. Imam, P.S.; Murali,B.V.; Ibrahim, M., Orient J. Chem., 2017, 33(2), 925-929.

13. Chao, M.V. Nature Reviews Neuroscience., 2003, 4(4), 299-309.

14. Shaikh, S.; Muneera, M.S,; Thusleem, O.A., Orient. J. Chem., 2013, 29(2), 579-87.

15. Russell, J.P.; Powell, D.J.; Cunnane, M.,Oncogene., 2000, 19(5), 5729-35.

16. Tognon,C.; Knezevich, S.R.; Huntsman, D., Cancer Cell., 2002, 2(5), 367-76.

17. Vaishnavi,A.; Capelletti,M.; Le,A.T., Nature Medicine., 2013, 19(11), 1469-72.

18. Wiesner, T.; He, J.; Yelensky, R., Nature Communications., 2014, 5, 3116-21.

19. Vaishnavi, A.; Le ,A.T.; Doebele,R.C., Cancer Discovery., 2015, 5(1), 25-34.

20. Hong,D.S.; Bauer,T.M.; Lee,J.J; Dowlati,A.; Brose, M.S.; Farago, A.F., Annals of Oncology., 2019, 30(2), 325-331.

21. Berger,S.;Martens,U.M.; Bochum,S., Recent Results Cancer Research., 2018, 211, 141-51.

22. Rolf, W.S.; Yaogeng,W.; Alfred,H.S.; Jan, H.M.S.; Jos,H.B., J. of Chrom. B., 2018, 10, 167-72.

23. Akram, N.M.; Umamahesh, M., Orient. J. Chem., 2017, 33(3), 1492-1501 